\title{
A Model for Enhancing the Competitiveness of MSMEs Through E-Commerce:
}

\author{
Study at MSMEs in Garut Region
}

\author{
Abdul Rahman*, Ervina \\ Lecturer in Public Sector Business, Administration Program \\ Polytechnic of STIA LAN Bandung \\ Bandung, Indonesia
}

\begin{abstract}
In theory, the competitiveness of a business unit is influenced by, among other things, the use of e- commerce in marketing activities. This study was conducted to determine the competitiveness of MSMEs and how E- Commerce affects this competitiveness. Based on Akhmedova's theory, the study was carried out on 46 MSMEs using E-Commerce in the Garut region. Through descriptive quantitative design, the study shows that MSMEs are competitive because they have access to finance, innovation, intellectual property, internationalization processes and the use of ICTs, human resources and governance. Interestingly, the competitiveness of MSMEs is supported by using ICT in the form of E-Commerce, which has a positive effect on the activities of business units. Thus, the study recommends a model for enhancing competitiveness through $\mathbf{E}$ Commerce with massive socialization; provision of hotspots; internet access programs; and application of models for all MSMEs, especially in the Garut Regency.
\end{abstract}

Keywords-competitiveness, marketing, e-commerce, MSMEs, increasing competitiveness

\section{INTRODUCTION}

The development of an era will never be separated from the business world [1]. Businesses that are increasingly in demand are forming Micro, Small, and Medium Enterprises/MSMEs $[2,3]$. MSMEs are able to make the economy of a region better [4] including the Garut Regency, West Java. Based on data from the MSMEs Office in Garut Regency, in 2016 there were 16,480 units, with business capital and assets of $\mathrm{Rp}$. 1,373,100,120,600, business volume of Rp. 1,034,783,747,300, and labor absorption of 55,332 people. Of the 16,480 MSMEs, 14,710 of them are at the micro scale with a labor absorption of 34,845 people. Micro business in its development has increased so that in 2018 it reached 51,931, with types of business in various sectors ranging from trade, processing/small industry, services, agriculture, fisheries, livestock, mining and others [5]. So that this MSMEs business can of course require competitiveness, not only from the product side, but also from the marketing side [6,7].
Marketing through information technology is becoming a trend among business actors [8,9]. This is due to the rapid advancement of technology that encourages business sectors, especially MSMEs, to take advantage of this technology online in marketing their products [10-12]. Business sectors cannot refuse the internet to develop their business. If there is rejection, MSMEs will find it difficult to develop products produced for consumers who need them [13-16].

Unfortunately, at this time, most business sectors still use traditional ways to sell their goods for various reasons [17]. This situation is of course very unfortunate because previous research states that there is an increase in the competitiveness of SMEs with network technology or what we often call the internet [18-21]. Of the various problems that occur, the authors are interested in conducting studies and further research to see the competitiveness of business actors who use E-Commerce through research entitled: "Competitiveness of MSMEs using E- Commerce in Garut Regency" with the aim of 1) knowing the competitiveness of MSMEs in Garut Regency; 2) knowing the competitiveness of MSMEs after using E-Commerce in Garut Regency; and 3) formulating models for the use of E-Commerce in increasing the competitiveness of MSMEs.

\section{LITERATURE REVIEW}

To answer the research objectives, the study used the competitiveness theory of Ahmedova [22]. According to him, the good competitiveness of a business unit includes at least 5 indicators, namely 1) financial access; 2) the existence of innovation activities (developing new knowledge or combining existing knowledge through new "entrepreneurial" ways); 3 ) the existence of intellectual property; 4) internationalization; 5) ICT, human resources, and strategic management.

In particular, Akhmedov said, that access to finance is reflected in the ease of borrowing money from family or friends /colleagues, ease of borrowing money in the bank, access to investment funds from investors, access to the current funds, the availability of funds for the purchase of machinery and equipment and availability of training funds for their employees. Then, the innovative activity is reflected in the 
changes in business processes inside the company with the aim of optimizing costs and reduce excess costs and the availability of promotional efforts or cooperation with other companies or universities.

From the point of view of intellectual property, it can be seen by the existence of attempts to be unique and better than their competitors, but also for the provision of patent rights on its uniqueness and for the registration of its trademark sign on legitimate grounds. Apart from that, it comes to internationalization, Akhmedov said, that business unit is to be focused on exports, import orientation, 50\% materials from imports, having abroad suppliers, cooperation in technology with foreign companies. Then participating in FDI (Foreign Direct Investment), taking part in international trade fairs, getting information about international markets and contacting with potential partners from foreign companies.

Finally, with the point of view of aspects of ICT, human resources and strategic management, Akhmedov said, that business unit, to be competitive, must promote organizational learning and management of knowledge, there is the practice of creating new knowledge, there is the practice of trying to get knowledge, there is the practice of trying to save knowledge, which is already there, there is the practice of sharing knowledge, there is the practice of application of the obtained knowledge. Besides that, the company should have a web page, use electronic signatures, providing online-orders (ecommerce), to apply information systems management, has trained personnel, there is a short-term business planning, there are medium-term business plan and no strategy for the development of marketing.

\section{RESEARCH METHODS}

Using descriptive quantitative approach [23-25] and in the theory of Akhmedova, the study, conducted on 46 MSMEs, in Garut Regency using e- commerce to market their products. Data collection is carried out through questionnaires and interviews.

\section{RESUlt AND DISCUSSION: COMPETITIVENESS OF MSMES}

\section{A. Ease of access to finance}

MSMEs in Garut Regency has easy access to finance to run its business. This is because of several factors, in fact including: 1) business ownership. The middle 91 percent of the ownership of the enterprise is in the property on the private, only the most minor about 9 percent belongs to the family, as a result of the union and others. It means that MSMEs has easy access to finance and to manage the business; 2) easiness to has capital from outside. Based on the report of the MSMEs Office in Garut Regency, easiness of MSMEs in getting finance access increases about 2 percent; and 3) Turnover per month. On average, 50 percent of MSMEs have a turnover of more than 10 million per month. By quite large turnover, it makes easier for MSMEs, to increase the capacity of competitiveness.

\section{B. Availability of innovative activity}

MSMEs has innovative activities, in the implementation of their business - activities, even if $65 \%$ of them are just running your business in for 1 to 3 years. Activity innovation evidenced in various products are produced in a range of product food products, such as the cakes are dry, chocolate, coffee, meatballs, chips $(76 \%)$ including crafts such as leather crafts and various accessories (11\%), and others (13\%). These innovative measures have been carried out in alone $(62 \%)$, with assistance from the part of their families $(13 \%)$ and on the employment of workers (25\%).

Innovative activity influences on the role of MSMEs office that has conducted IT training for product marketing, product design training for promoting and the selection of MSMEs ambassadors to promote MSMEs products including the existence of Parigel as, which is a coop formed by the MSMEs office to help promote product innovation through the provision of galleries and cars for sale around.

\section{Intellectual property}

Some MSMEs, such as the craft leather, has registered its trademark, to obtain a patent. Then, a few units of the business also have obtained HALAL certification by the program certification from MSMEs office. It is proven that MSMEs already have the right of ownership to the intellectual.

\section{Internationalization}

Products result of MSMEs have been doing the internationalization process. Most of the products $(49 \%)$ are sold to other areas or cities in Indonesia. Even $10 \%$ have already go international. The remaining $41 \%$ of the products are scattered in the Garut area.

\section{E. ICT, Human Resources and management strategy}

MSMEs has used the information technology to marketing (e- commerce). Most of them (64\%) using the social network, such as the facebook/Instagram/ twitter/whatsapp and Line as means of e -commerce. Others use website provided by the MSMEs Office $(21 \%)$ marketplace $(9 \%)$, application of Grab/Gojek (3\%) and by the private site (3\%). Skills for human resources and management strategic are obtained by training from MSMEs Office.

\section{RESULTS}

According to the implementation of marketing with ecommerce. The study results that: 1) around 87 percent of managing e- commerce are conducted by self. The rest (13\%) are managed by family members, administrative personnel, as well as IT-personnel; 2) about 91 percent of MSMEs keep in the existing structure after the use of e- commerce. Only $4 \%$ have changed their business - organization structure, to be lower or be more complicated; 3) average of 91 percent of MSMEs do not change the number of employees. Only 9 percent change the composition of employees; 4) Productivity of MSMEs increased after using e-commerce (46\%). 
Otherwise, the productivity of work remains stable (54\%); 5) the demand of product grows up 65 percent after using of ecommerce, only slightly, which has the tendency to remain and reduce $(35 \%) ; 6)$ sale of products increases $(65 \%)$ after taking e- commerce, in the time as the 35 percent of reported fixed and reduced; 7) turnover of sale goes up around 65 percent after employing e- commerce than with the help of electronic commerce. Only the most insignificant were reported fixed and decreased $(35 \%) ; 8)$ cost of production is not change after using e- commerce (70\%), only respectively $15 \%$ were recorded the cost of production increases and decreases; and 9) the profit of MSMEs increased to 65 percent with e-commerce, 33 percent fixed, and only 2 percent are reported decrease.

Refer to the result, this study formulates a model for enhancing the competitiveness of MSMEs through ecommerce as follows (figure 1):

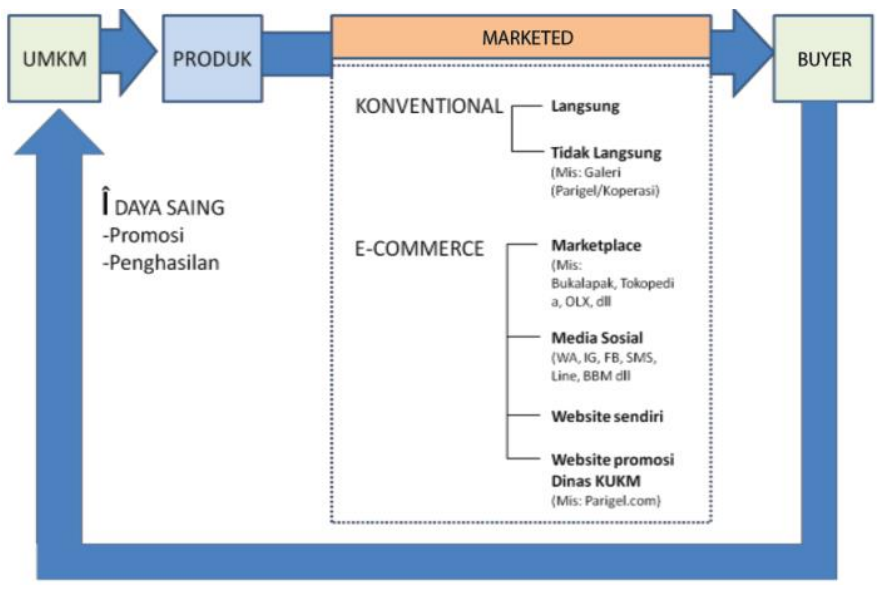

Fig. 1. Model.

With this model, the study expects that the capacity of competitiveness, which is already owned by the MSMEs in Garut Regency can be improved by combining conventional marketing and e-commerce, minimum in the aspect of promotion and income. Then the model expectedly will be applied by MSMEs in Garut regency that still sell their products by conventional manner, so that the competitiveness can be increased.

\section{CONCLUSION AND RECOMMENDATION}

MSMEs in Garut Regency already have competitive in business because of easiness to access of finance, innovation of activity, having intellectual property, internationalization of product by export orientation, and using information technology in marketing through website from MSMEs office.

The use of e- commerce has a positive effect on the competitiveness of MSMEs in Garut Regency. This is because, that after the use of e-commerce: 1) organizational structure is not changed; 2) the number of employees who have not changed; 3 ) productivity were increased; 4) demand increased, it is not only in the area of Garut, but in other cities in Indonesia including abroad; 5) sales were enhanced; 6) turnover of business have been growth up; 7) production costs are fixed; and 8) profit to be increased.

According to applying E-commerce and the effect of it, the study formulated a model by combining the use of $\mathrm{E}$ commerce and conventional marketing to enhance the competitiveness of MSMEs. The study also recommends: 1) the existence of socialization by attending a business to increase the level of awareness of MSMEs to use E- commerce approach in improving the competitiveness of enterprises; 2) providing a free wi-fi access to help MSMEs in getting Internet access; 3) applying models formulated for all MSMEs in Garut Regency.

\section{REFERENCES}

[1] B. Alma, "Business Introduction". Bandung, 2012: Alfabeta.

[2] A. Abdullah et al. "Regional Competitiveness Concepts and Measurements in Indonesia. Center for Central Banking Education and Studies, Bank Indonesia”. Yogyakarta: BPFE, 2002.

[3] J. Christanto, "Building Regional Competitiveness through the creation of Regional Core Competencies". Yogyakarta: Deepublish, 2011.

[4] Z. Zimmerer, W. Thomas and M. Norman, Scarborough. "Essential of Entrepreneurship and Small Business Management". Jakarta: Salemba Empat, 2009.

[5] MSMEs Office Garut Regency. "Report of Performance”, 2016-2018

[6] P. Kotler and G. Amstrong, "Marketing Principles, Volume II". Jakarta: Erlangga, 2001

[7] H.P. Harefa, SWOT, Strategy Analysis of Increasing Competitiveness in Joint Supermarkets. Essay. Medan: USU, 2014.

[8] J.A. O'Brien, "Introduction of Information System". Terj. Fitriasari, Dewi dan Deny Arnos Kwary. Jakarta: SalembaEmpat, 2006.

[9] H. Humdiana and E. Indrayani, "Management Information System". Yogyakarta: Graha Ilmu, 2006.

[10] C. Jinling, et all. "Modeling E-Commerce Website Quality with Quality Function Deployment", IEEE International Conference on Deployment e-Business Engineering. 21-23 Oct.2009.

[11] J. Jauhari, "Small and Medium Enterprises Development Efforts by Utilizing E-Commerce”. Jurnal Sistem Informasi, (Online), Vol.2 No.1, 2010.

[12] R.N. Herdianti, "The Role of the Government in Utilizing E- Commerce by SMEs in the Kotagede Silver Craft Industry". Thesis. Yogyakarta, 2014.

[13] R. Javalgi and R. Ramsey, "Strategic Issue of E-Commerce as an Alternative Global Distribution System, International Marketing Review". 18(4): 376-391, 2001

[14] R. Masyita and S. Hanoum, "Analysis of the Factors Affecting the Use of the Internet on the Performance Improvement of SMEs Using the Structural Equation Modeling Method". Jurnal Teknik ITS Vol. 1, ISSN: 2301- 9271. 2012

[15] P. Pebruati, Handayani, and Zahroh., "The Effect of Information Technology Applications in Increasing Company Competitiveness (Study on Malang City SMEs)". Jurnal Provir Volume 7 No. 1, Hal: 14. 2012

[16] R.S. Wardhani and Y. Agustina, "Analysis of Factors Affecting Competitiveness in Bangka Typical Food Industry Centers in Pangkalpinang City". Jurnal Akuntansi Universitas Jember. Surabaya, 64-69. 2015.

[17] H. Susanto, "Analysis of Factors Affecting Perceptions of Batik Business Actors in Yogyakarta City Facing the 2015 Asean Economic Community". University Research Colloquium 201.ISSN 2407-9189, 2015 . 
[18] R. Ustadiyanto, "Framework E-Commerce, First edition".Yogyakarta Penerbit Andi, 2001.

[19] M.E. Porter, "Strategy of Competitiveness". Terj. Sigit Suryanto. Kharisma Publishing Group: Tangerang, 2010.

[20] S. Slamet and S.A. Idrus, "Application of E-Commerce as a Global Competitiveness Small \& Medium Enterprise Development Effort", Penelitian Ilmu Pengetahuan Terapan LPP UIN. Malang, 2010.

[21] N. Terzi, "The Impact of E-Commerce on International Trade and Employment.Social and Behavior Sciences", 24: 745-753, 2011.
[22] S. Ahmedova, "Factors for Increasing the Competitiveness of Small and Medium-Sized Enterprises (SMEs) In Bulgaria. Procedia-Social and Behavioral Sciences, 195: 1104-1112, 2015.

[23] N. Indrianto and B. Supomo, "Business Research Methodology, For Accounting \& Management". Yogyakarta: BPFE, 2002.

[24] M. Nisfiannoor, "Modern Statistical Approach to Social Sciences". Jakarta: Salemba Empat, 2008.

[25] S. Sugiyono. "Statistics for Research". Bandung: Penerbit Alfabeta, 2010. 